\title{
Temporal and Spatial Variations in Soil TOC, $T N$, and TP, and their Relationships in Bioretention Tanks
}

\author{
Chao Guo, Jiake Li*, Huaien Li, Zengchao Liu, Peng Li \\ State Key Laboratory of Eco-hydraulics in Northwest Arid Region of China, \\ Xi' an University of Technology, Xi' an, P.R. China
}

Received: 8 October 2017

Accepted: 8 December 2017

\begin{abstract}
This study aims to explore the temporal and spatial variations of soil total organic carbon (TOC), total nitrogen (TN), total phosphorus (TP), and the relationships between $\mathrm{C} / \mathrm{N}, \mathrm{C} / \mathrm{P}$ and TOC, TN, and $\mathrm{TP}$ in bioretention tanks. Two bioretention tanks (tank No. 1: depth of $0 \sim 20 \mathrm{~cm}$ was vacant aquifer layer, 20 90 cm, filled with planting soil, 90 105 cm, filled with gravel; tank No. 3: 0 20 cm was aquifer layer, $20 \sim 50 \mathrm{~cm}$, filled with planting soil, $50 \sim 90 \mathrm{~cm}$, filled with blast furnace slag and sand; $90 \sim 105 \mathrm{~cm}$, filled with gravel) were used in simulation stormwater runoff purification experiments to collect planting soil samples at intervals of one hour before inflow and 24 hours after the end of inflow. The results revealed that soil TN, TP, and TOC in 2 bioretention tanks were mainly concentrated at $10 \sim 30 \mathrm{~cm}$ in soil. The contents of TN and TP varied from $0.32 \mathrm{~g} \mathrm{~kg}^{-1}$ to $0.50 \mathrm{~g} \mathrm{~kg}^{-1}$ and from $0.83 \mathrm{~g} \mathrm{~kg}^{-1}$ to $1.35 \mathrm{~g} \mathrm{~kg}^{-1}$ within the investigated zone, respectively. Soil TN content in the 2 bioretention tanks before the inflow was slightly greater than after the inflow, but the opposite was true for TP, as it was less before the inflow than after. The potential of TN and TP fixation in No. 1 was higher than that in No, 3 within the upper $30 \mathrm{~cm}$ depth, which were related to the infiltration rate of underlying fillers (the underlying fillers of No. 1 is planting soil, and which is the blast furnace slag and sand in No. 3). The TOC content in the 2 bioretention tanks varied from $4.24 \mathrm{~g} \mathrm{~kg}^{-1}$ to $8.97 \mathrm{~g} \mathrm{~kg}^{-1}$, and the average contents decreased with the increasing depths. The $\mathrm{C} / \mathrm{N}$ and $\mathrm{C} / \mathrm{P}$ were positively correlated with $\mathrm{TOC}$, while they were negatively correlated with TN and TP contents, which showed that soil $\mathrm{C} / \mathrm{N}$ and $\mathrm{C} / \mathrm{P}$ were mainly controlled by TOC in soil. The conclusions can provide references for the design and operation evaluation of bioretention facilities.
\end{abstract}

Keywords: bioretention tank, soil, TOC, TN, TP

*e-mail: xaut_ljk@163.com 


\section{Introduction}

With increasing of impervious urban surfaces in recent decades, runoff is increased, resulting in accelerated erosion rates [1]. Many cities, such as Xi'an in Shaanxi, China, can even "see the sea" in the case of a rainstorm. Meanwhile, tire chafing, sole friction, air dust, and industrial and construction wastes are discharged into rivers or infiltrated directly. These materials form the main pollution sources, which not only pollute rivers or lakes but also affect groundwater [2-3]. Thus, the reduction of the amount of urban road runoff and the pollutants remains a challenge in municipal and environmental science [4-5]. In order to slow the progression of the urban peak flow from the source, urban green sunken belts on both sides of the road should be used to collect or purify stormwater runoff. This process is not only energy efficient and environment friendly but can improve the comprehensive drainage potential of the catchment area. Urban road green sunken belt, also called ecological filter or bioretention tank (low-impact development rainstorm management strategy or technology), has significantly reduced rain flood and purified stormwater runoff [6-7]. In the early 1990s, Prince George's County in Maryland, USA, applied a bioretention system for the first time to replace traditional non-point source pollution control, namely, best management practices (BMPs) [8]. The structure design, experiment, and hydrological or data simulation of the bioretention system has been investigated thereafter in the United States, the United Kingdom, Australia, Germany, New Zealand, and other countries [9-10]. However, long-term exploration for rainwater purification mechanism, system, and other actual running effects remains limited.

As a typical bioretention filter medium, soil possesses a high stormwater runoff accumulation or purification capacity, which directly affects the effectiveness of a bioretention system [11]. C, N, and P are the most important elements in a bioretention system. The existence and conversion of these elements in soil have been progressively conducted in the the United States and other countries in the fields of agricultural development and environmental protection [12-13]. Lozano-García et al. [14] demonstrated that soil C, N, and P are important ecological factors that affect land management, nutrient cycling, and ecosystem health maintenance. The contents of these elements also affect soil microorganism quantity and litter decomposition rate, as well as the long-term accumulation of soil TOC and nutrients. Zhi et al. [13] studied the removal of pollutants in tidal flow-constructed wetlands at the molecular level and demonstrated that the removal rates of $\mathrm{NH}_{4}^{+}, \mathrm{NO}_{3}^{-}$, and $\mathrm{TN}$ were $76 \%, 97 \%$, and $93 \%$, respectively. Thus, studies on $\mathrm{N}$ and $\mathrm{P}$ in the filter medium of environmentally friendly bioretention facilities, such as a rain garden or biological filter system, should be further strengthened [15-16].

Parolari and Porporato [17] demonstrated that soil carbon and nitrogen ratio $(\mathrm{C} / \mathrm{N})$, whose value influences soil $\mathrm{N}$ cycle, is a sensitive indicator of soil quality, particularly $\mathrm{N}$ nutrient balance and mineralization capacity. A low $\mathrm{C} / \mathrm{N}$ can accelerate microbial decomposition and $\mathrm{N}$ mineralization rates. By contrast, a high $\mathrm{C} / \mathrm{N}$ limits soil microbial activity, slows down the decomposition and mineralization rates of organic matter and organic N, and increases the soil fixation capacity on organic carbon, which helps to hold the $\mathrm{N}$ in rainfall. Yang et al. [18] reported that soil carbon and phosphorus (C/P) ratio can account for the available $\mathrm{P}$ content in soil. A low $\mathrm{C} / \mathrm{P}$ can accelerate the organic matter decomposition by microbes to release nutrients, so the available $P$ content is high, which negatively affects $\mathrm{P}$ immobilization. A high $\mathrm{C} / \mathrm{P}$ indicates the assimilation of microbes to available $\mathrm{P}$ in soil, and this phenomenon is prone to happen with microbes and crops to competitively absorb the available $\mathrm{P}$ in soil. Therefore, the high $\mathrm{C} / \mathrm{P}$ indicates great potential for $\mathrm{P}$ fixation in soil [19]. In conclusion, the contents of $\mathrm{C}, \mathrm{N}$, and $\mathrm{P}$ and their relationships in the bioretention system determine soil nutrient variations and indicate the effectiveness of purifying urban stormwater runoff by the soil media. Thus, $\mathrm{C}, \mathrm{N}$, and $\mathrm{P}$ contents as well as $\mathrm{C} / \mathrm{N}$ or $\mathrm{C} / \mathrm{P}$ are necessary to be studied to improve management and mastery of purification or immobilization of $\mathrm{N}$ and $\mathrm{P}$ in stormwater runoff [19-20].

In this study, theoretical analysis and field-based experiments were performed to determine temporal and spatial variations in soil TOC, TN, and TP and their relationships in bioretention tanks. It can provide references for the design and operation evaluation of bioretention facilities.

\section{Materials and Methods}

\section{Experimental Device}

This study was conducted at the outdoor testing ground of the Key Laboratory of Northwest Water Resource and Environment Ecology of the ministry of education, where 10 bioretention tanks from were designed and constructed at Xi'an University of Technology in Xi'an Shaanxi, China, in 2013. Tank Nos. 1 and 3 were selected for testing and research in this paper. Tank No. 1 refers to a simple bioretention tank without artificial fillers and tank No. 3 is a complex bioretention tank including artificial fillers. The research aims to explore temporal and spatial variations of soil TOC, TN, and TP with different functional layers in both tanks. The two bioretention tanks have the same size $(\mathrm{L} \times \mathrm{W} \times \mathrm{H}=200$ $\times 50 \times 105 \mathrm{~cm}$ ), and the functional layers in No. 1 are as follows: 0 $20 \mathrm{~cm}$ aquifer layer, $20 \sim 90 \mathrm{~cm}$ layer filled with the planting soil, and 90 105 $\mathrm{cm}$ layer filled with gravel; No. 3: 0 20 cm aquifer layer, 20 50 cm layer filled with the planting soil, 50 90 cm layer filled with blast furnace slag mixing sand (1:1 by volume), and 90 105 cm layer filled with gravel. Permeable geotextile was used to separate every 2 layers. The bottom of the 2 bioretention tanks is permeable, and the upper area was planted with 4 rows of Lobular Privet with 2 straius each row and six 

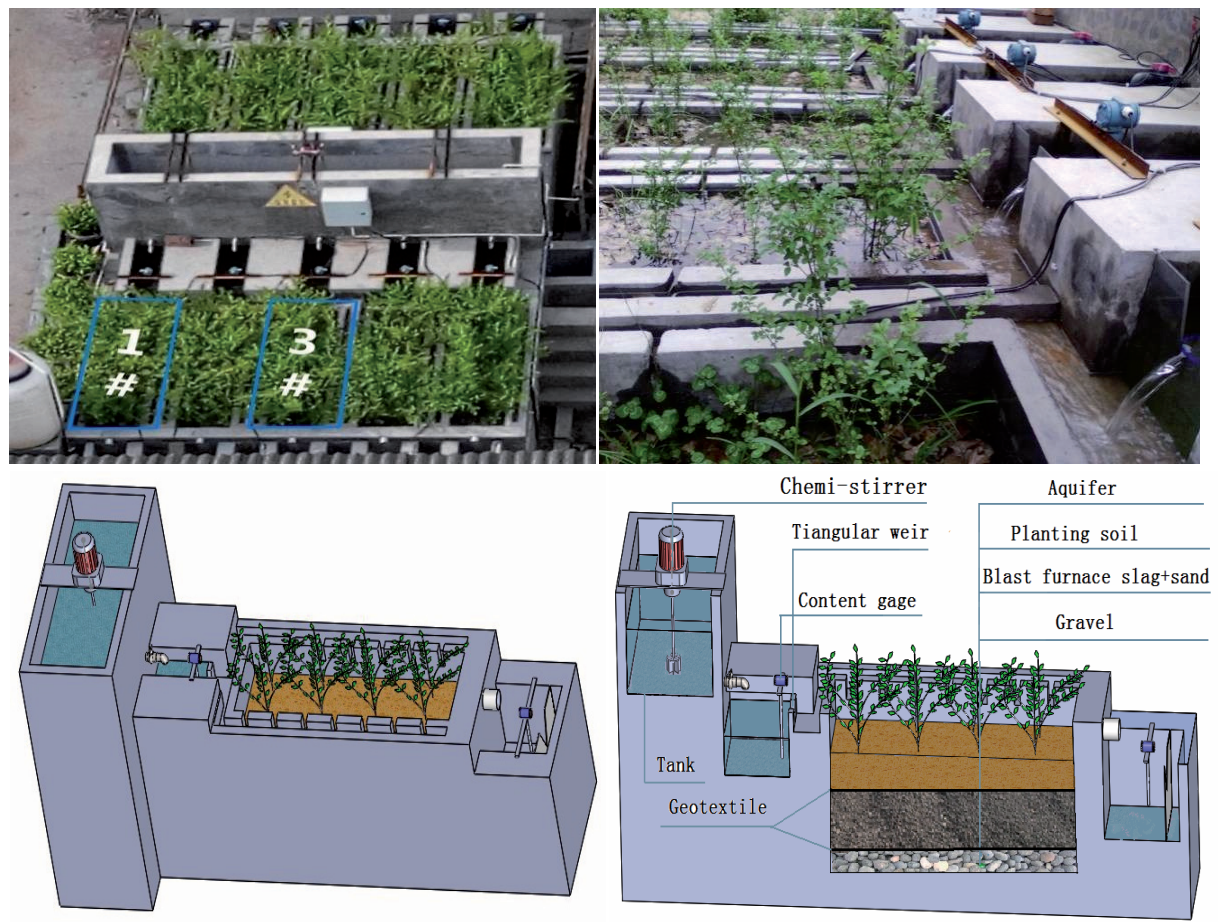

Fig. 1. Schematic of the device.

rows of Ophiopogon japonicas with four straius each row. Waterproof cloth was used to cover the bioretention tanks in case of rain. The schematic is shown in Fig. 1.

\section{Test Water}

Experimental water was the synthesized simulation stormwater runoff according to the investigation of water quality on road runoff in China and the monitoring results of water quality on road runoff by our research group. The water quality of stormwater runoff at the middle and late stage in Xi'an was referred to prepared test water. Table 1 shows the simulation stormwater runoff quality, treatment, and chemicals added to the test water. A high concentration of test water added with fertilizers was prepared in the laboratory and diluted in proportion to the required concentration. Inflow water quantity was determined using the rainstorm intensity formula of Xi'an city derived by Lu et al. [21], which is shown in Formula (1). The inflow duration time was set as 1 hour at a time. Designed influent water quantity is shown in Table 2 .

$$
q=\frac{2785.833 \times(1+1.1658 \lg P)}{(t+16.813)^{0.9302}}
$$

\section{Experimental Process and Sample} Collection

The test process is illustrated in Table 3. The experiment began on May 6, 2014, and the soil temperature from the start-up stage to the end ranged from $21.5^{\circ} \mathrm{C}$ to $37.0^{\circ} \mathrm{C}$. In order to obtain the temporal and spatial variations of $\mathrm{TOC}, \mathrm{TN}$, and $\mathrm{TP}$ in soil of bioretention tanks, soil core samples of $10 \mathrm{~cm}, 30 \mathrm{~cm}$, and $50 \mathrm{~cm}$ in No. 1 and $10 \mathrm{~cm}, 20 \mathrm{~cm}$, and $30 \mathrm{~cm}$ in No. 3

Table 1 . Water quality of road surface runoff in Xi' an city and experimental water quality.

\begin{tabular}{|c|c|c|c|c|c|c|c|c|}
\hline \multicolumn{2}{|r|}{ Items } & $\begin{array}{c}\text { COD } \\
\left(\mathrm{mg} \mathrm{L}^{-1}\right)\end{array}$ & $\begin{array}{c}\mathrm{TN} \\
\left(\mathrm{mg} \mathrm{L}^{-1}\right)\end{array}$ & $\begin{array}{c}\mathrm{NH}_{4}-\mathrm{N}(\mathrm{mg} \\
\left.\mathrm{L}^{-1}\right)\end{array}$ & $\begin{array}{c}\mathrm{TP} \\
\left(\mathrm{mg} \mathrm{L}^{-1}\right)\end{array}$ & $\begin{array}{c}\mathrm{Zn} \\
\left(\mathrm{mg} \mathrm{L}^{-1}\right)\end{array}$ & $\begin{array}{c}\mathrm{Cd} \\
\left(\mathrm{mg} \mathrm{L}^{-1}\right)\end{array}$ & $\begin{array}{c}\mathrm{Pb} \\
\left(\mathrm{mg} \mathrm{L}^{-1}\right)\end{array}$ \\
\hline \multirow{2}{*}{$\begin{array}{l}\text { Road runoff } \\
\text { water quality } \\
\text { in Xi'an }\end{array}$} & Initial rainwater & 600 & 13 & 2.3 & 5.6 & 1.5 & 0.040 & \\
\hline & $\begin{array}{l}\text { Medium and latter } \\
\text { rainwater }\end{array}$ & 200 & 6 & 1.5 & 1.5 & 0.2 & 0.015 & \\
\hline \multirow{3}{*}{$\begin{array}{c}\text { Prepared water } \\
\text { quality }\end{array}$} & High concentration & 600.00 & 14.00 & 6.00 & 2.50 & 1.50 & 0.05 & 0.85 \\
\hline & Medium concentration & 400.00 & 10.00 & 4.00 & 1.50 & 1.00 & 0.03 & 0.45 \\
\hline & Low concentration & 200.00 & 6.00 & 2.00 & 0.50 & 0.50 & 0.01 & 0.05 \\
\hline $\begin{array}{c}\text { Using } \\
\text { chemicals }\end{array}$ & Chemicals & Glucose & Nitrate & $\begin{array}{l}\text { Ammonium } \\
\text { chloride }\end{array}$ & $\begin{array}{l}\text { Monopotassium } \\
\text { phosphate }\end{array}$ & $\begin{array}{l}\text { Zinc } \\
\text { sulfate }\end{array}$ & $\begin{array}{l}\text { Cadmium } \\
\text { nitrate }\end{array}$ & $\begin{array}{l}\text { Lead } \\
\text { nitrate }\end{array}$ \\
\hline
\end{tabular}


Table 2. Designed influent water quantity.

\begin{tabular}{|c|c|c|c|c|c|c|c|}
\hline & $\begin{array}{c}\text { Recurrence } \\
\text { interval } \\
(\mathrm{P} / \mathrm{a})\end{array}$ & $\begin{array}{c}\text { Rainstorm } \\
\text { intensity } \\
\left(\mathrm{q} / \mathrm{L} \mathrm{s}^{-1} \mathrm{ha}^{-1}\right)\end{array}$ & $\begin{array}{c}\text { Contributing } \\
\text { area } \\
(\mathrm{F} / \mathrm{ha})\end{array}$ & $\begin{array}{c}\text { Runoff } \\
\text { coefficient } \\
(\psi)\end{array}$ & $\begin{array}{c}\text { Rainwater } \\
\text { duration time } \\
(\mathrm{t} / \mathrm{min})\end{array}$ & $\begin{array}{c}\text { Design flow } \\
\left(\mathrm{v}^{\left.-\mathrm{L} \mathrm{s}^{-1}\right)}\right.\end{array}$ & $\begin{array}{c}\text { Total Inflow } \\
(\mathrm{V} / \mathrm{L})\end{array}$ \\
\hline Big inflow & 5 & 89.118 & 0.0017 & 0.9 & 60 & 0.136 & 491 \\
\hline $\begin{array}{c}\text { Medium } \\
\text { inflow }\end{array}$ & 2 & 66.338 & 0.0017 & 0.9 & 60 & 0.101 & 365 \\
\hline Small inflow & 0.5 & 31.872 & 0.0017 & 0.9 & 60 & 0.049 & 176 \\
\hline
\end{tabular}

under the subsurface were collected one hour before the inflow and 24 hours after the end of the inflow using a soil sample collector. Because there is a piece of permeable geotextile at $30 \mathrm{~cm}$ under the media in No. 3, only the soil samples at $30 \mathrm{~cm}$ were collected. Each sample was about $10 \mathrm{~g}$ collected at 3 different locations in a concentric circle. Three different samples of each depth were mixed as a test soil sample, and grassroots were removed. Then the samples of different depths were placed in the shade to dry naturally, and the sample holes were backfilled immediately. Each of the test samples was passed through the sieve of $0.25 \mathrm{~mm}$. One part of the undersized soil was used to determine the TN and TP [22-23], and the rest was used to test TOC [24]. The sub-samples were stored in a refrigerator at $-20^{\circ} \mathrm{C}$ after the previous treatment, and soil analysis was completed within one week. TN and TP were measured by a fully automatic intermittent chemical analyzer (Smartchem300, Italy), and TOC was measured by a total organic carbon analyzer (Vario TOC, Germany). All variables were analyzed according to the stansard analytical procedures. The software of Sigma-Plot and SPSS were used for data analysis.

\section{Results and Discussion}

$\mathrm{TN}$ and TP Variations in Bioretention Tanks

\section{Temporal Variations of TN and TP}

NandP are importantelements in soil, and their contents can illustrate the amount intercepted or immobilized by soil when stormwater runoff enters the bioretention tanks [11]. It shows that $\mathrm{TN}$ content from 12 May to 6 June was high and then declined in the 2 bioretention tanks (Figs 2a-b). This result may be due to $\mathrm{N}$ accumulation of previous experiments in the media and $\mathrm{N}$ in the air entered the bioretention tanks via dry and wet deposition before this experiment. A portion of $\mathrm{N}$ was intercepted on soil surface in the particle state, whereas the other parts were absorbed by soil in the ionic state through nitrification and denitrification as well as other physical and chemical mechanisms. Thus, the soil $\mathrm{N}$ content was high in the early stage. With the temperature increasing gradually in summer in Xi'an (from June to August), plants grow vigorously, and enzyme and microbial activity increased in soil, therefore the need and consumption for $\mathrm{N}$ was

Table 3. Test process of inflow time and sampling time.

\begin{tabular}{|c|c|c|c|c|c|c|c|c|}
\hline Sampling times & 1 & 2 & 3 & 4 & 5 & 6 & 7 & 8 \\
\hline Inflow time & $\begin{array}{l}\text { May } 12^{\text {th }} \\
\text { at } 8 \text { a.m }\end{array}$ & & $\begin{array}{l}\text { May } 22^{\text {nd }} \\
\text { at } 8 \text { a.m }\end{array}$ & & $\begin{array}{l}\text { June } 6^{\text {th }} \\
\text { at } 7 \text { a.m }\end{array}$ & & $\begin{array}{l}\text { June } 21^{\text {st }} \\
\text { at } 7 \text { a.m }\end{array}$ & \\
\hline Sampling time & $\begin{array}{l}\text { May } 12^{\text {th }} \\
\text { at } 7 \text { a.m }\end{array}$ & $\begin{array}{l}\text { May } 14^{\text {th }} \\
\text { at } 9 \text { a.m }\end{array}$ & $\begin{array}{l}\text { May } 22^{\text {nd }} \\
\text { at } 7 \text { a.m }\end{array}$ & $\begin{array}{l}\text { May } 24^{\text {th }} \\
\text { at } 9 \text { a.m }\end{array}$ & $\begin{array}{l}\text { June } 6^{\text {th }} \\
\text { at } 6 \text { a.m }\end{array}$ & $\begin{array}{l}\text { June } 8^{\text {th }} \\
\text { at } 8 \text { a.m }\end{array}$ & $\begin{array}{l}\text { June } 21^{\text {st }} \\
\text { at } 6 \text { a.m }\end{array}$ & $\begin{array}{l}\text { June } 23^{\text {rd }} \\
\text { at } 8 \text { a.m }\end{array}$ \\
\hline Influent water quantity, & SF & & MF & & $\mathrm{BF}$ & & $\mathrm{BF}$ & \\
\hline $\begin{array}{l}\text { Influent water } \\
\text { concentration }\end{array}$ & $\mathrm{LC}$ & & $\mathrm{MC}$ & & $\mathrm{HC}$ & & $\mathrm{MC}$ & \\
\hline Sampling times & 9 & 10 & 11 & 12 & 13 & 14 & 15 & \\
\hline Inflow time & $\begin{array}{l}\text { July } 1^{\text {st }} \\
\text { at } 7 \text { a.m }\end{array}$ & & $\begin{array}{l}\text { July } 11^{\text {th }} \\
\text { at } 7 \text { a.m }\end{array}$ & & $\begin{array}{l}\text { July } 21^{\text {st }} \\
\text { at } 7 \text { a.m }\end{array}$ & & $\begin{array}{l}\text { August } 5^{\text {th }} \\
\text { at } 7 \text { a.m }\end{array}$ & \\
\hline Sampling time & $\begin{array}{l}\text { July } 1^{\text {st }} \\
\text { at } 6 \text { a.m }\end{array}$ & $\begin{array}{l}\text { July } 3^{\text {rd }} \\
\text { at } 8 \text { a.m }\end{array}$ & $\begin{array}{l}\text { July } 11^{\text {th }} \\
\text { at } 6 \text { a.m }\end{array}$ & $\begin{array}{l}\text { July } 13^{\text {th }} \\
\text { at } 8 \text { a.m }\end{array}$ & $\begin{array}{l}\text { July } 21^{\text {st }} \\
\text { at } 6 \text { a.m }\end{array}$ & $\begin{array}{l}\text { July } 23^{\text {rd }} \\
\text { at } 8 \text { a.m }\end{array}$ & $\begin{array}{l}\text { August } 7^{\text {th }} \\
\text { at } 6 \text { a.m }\end{array}$ & \\
\hline Influent water quantity, & $\mathrm{SF}$ & & MF & & $\mathrm{BF}$ & & SF & \\
\hline $\begin{array}{l}\text { Influent water } \\
\text { concentration }\end{array}$ & $\mathrm{HC}$ & & $\mathrm{LC}$ & & $\mathrm{MC}$ & & $\mathrm{HC}$ & \\
\hline
\end{tabular}

Note: HC: High concentration; MC: Medium concentration; LC: Low concentration.

BF: Big flow; MF: Medium flow; SF: Small flow 
increased [14]. The plants grow luxuriantly with the developed root system as the environment temperature increased. The enhanced ability of oxygen transport and increased recurrent oxygen in the soil led to an increase in $\mathrm{N}$ demand. Furthermore, the increased enzyme activity might improve the ability of nitrification bacteria and denitrification bacteria on $\mathrm{N}$ decomposition, resulting in simultaneous nitrification, anammox, and denitrification to transform nitrogen into gaseous $\mathrm{N}$ and promote its entry into the atmosphere [25]. Meanwhile, 2 big flow processes happened on 6 and 21 June (Table 3), during which a part of soil $\mathrm{N}$ was forced to discharge through erosion or leaching. Thus, the TN content declined within a short period of time. At the same time, the TN content at $50 \mathrm{~cm}$ was slightly lower than those at 10 and $30 \mathrm{~cm}$ of No. 1 (Fig. 2a). TN contents in the 2 bioretention tanks were mainly concentrated at $10 \sim 30 \mathrm{~cm}$ in soil. A large number of particulate $\mathrm{N}$ was intercepted at the upper soil during rain simulation because the bioretention tank was covered by plants. Therefore, the soil TN content at the upper layer was higher than that at the lower layer.

Figs 2(c-d) show the TP content $\left(0.83 \mathrm{~g} \mathrm{~kg}^{-1}\right.$ to $\left.1.35 \mathrm{~g} \mathrm{~kg}^{-1}\right)$ in the bioretention tanks. The TP content in the first 4 samples slightly decreased 12-24 May. This result may be associated with the low inflow concentration. The TP content in the soil increased on 24 May and 6 June, with the high and medium inflow concentrations from 6-21 June. The TP absorption by soil media was enhanced with increasing inflow concentration. The decrease in soil TP content after 1 July could be due to the fact that a part of available $P$ can be easily absorbed by plants and changed with plant growth. The
TP content declined later and was also probably related to the media sampling. When the inflow rapidly infiltrated into the macropore within a short residence time, and the filtration or absorption by the bioretention tanks cannot be completely facilitated [26]. In addition, PP adsorbed on the suspension surface was washed and spalled by the inflow as well as forced to discharge during dissolution. Moreover, the TP content at $50 \mathrm{~cm}$ in No. 1 was slightly lower than those at 10 and $30 \mathrm{~cm}$ (Fig. 2c). This result indicated that a large part of $\mathrm{P}$ was intercepted on the soil surface and mainly concentrated at $10 \sim 30 \mathrm{~cm}$. Other studies demonstrated that particle pollutants that subsided on the soil surface are prone to filtration and absorption by soil media and cannot penetrate the soil at $5 \sim 20 \mathrm{~cm}$ [27]. Morales et al. [28] reported that the biological system intercepted nearly all particulate phosphorus (PP), such that the optimal effect of the bioretention system on filtering PP was achieved.

\section{Spatial Variations of TN and TP}

Through calculating the average TN and TP contents before inflow for all simulation storm runoff events, the variations of the average $\mathrm{TN}$ and $\mathrm{TP}$ contents before and after the inflow are shown in Figs 3(a-b). The TN contents were higher before the inflow than after except the depth of $30 \mathrm{~cm}$ in No. 1 and $10 \mathrm{~cm}$ in No. 3. This result demonstrated that some $\mathrm{N}$ in soil leached under the scouring of stormwater runoff in the bioretention tanks [29]. That is, some $\mathrm{N}$ in media was forced to discharge without undergoing the entire physical, chemical, and biological reactions when the simulated rain entered
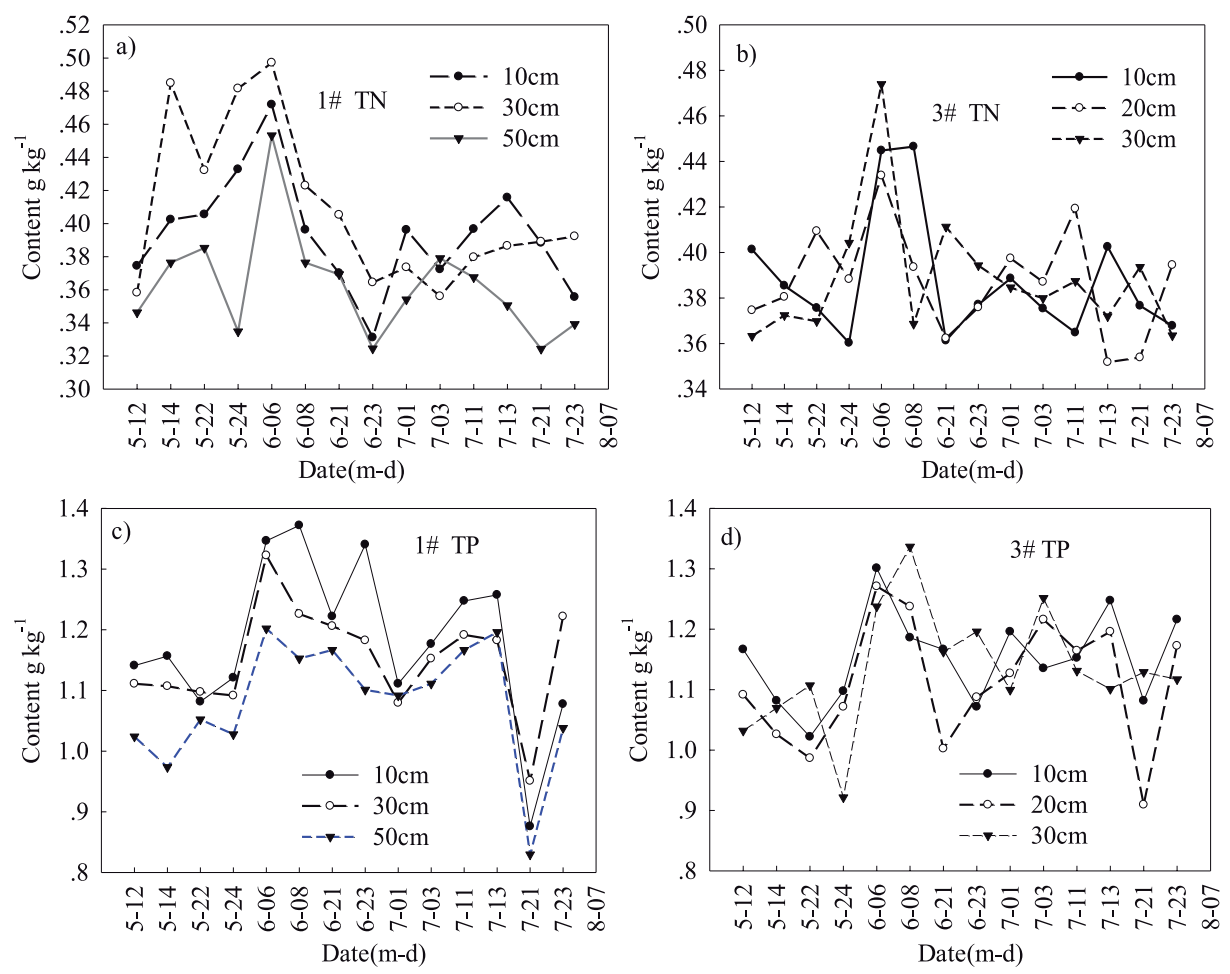

Fig. 2. Temporal variations in TN and TP in bioretention tanks. 

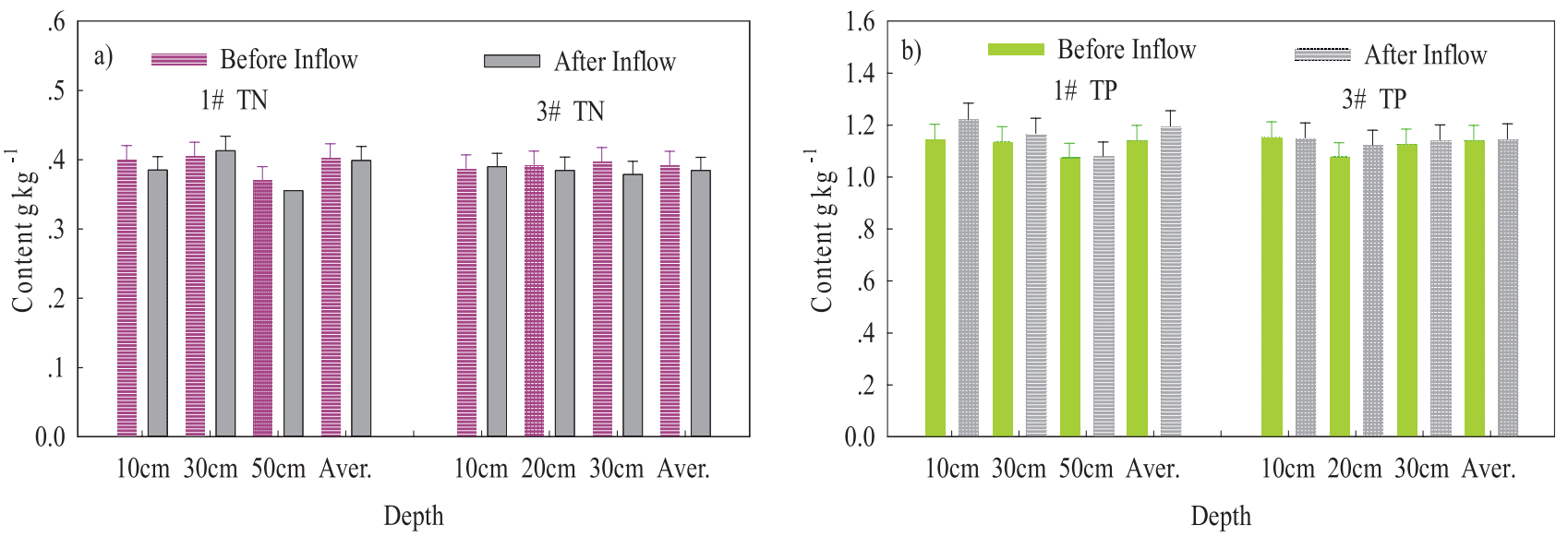

Fig. 3. Spatial distributions of TN and TP before and after inflow.

Note: Before inflow: The average content of TN before inflow at different depths during the whole experimental process. After inflow: The average content of TN after inflow at different depths during the whole experimental process. Aver.: The average contents of TN and $\mathrm{TP}$ at $10 \mathrm{~cm}$ and $30 \mathrm{~cm}$ in two tanks before and after inflow.

the tank. It shows that at the same depth $(10 \mathrm{~cm})$, the TN content before the inflow in No. 1 was higher than that afterward, while the situation was reversed in No. 3 (Fig. 3a). As the depth increased to $30 \mathrm{~cm}$, the TN content before the inflow became lower than that afterward in No. 1, in contrast to that in No. 3. With inflow continuing, the compactness of the media below
$30 \mathrm{~cm}$ depth in No. 1 was improved greater than that in No. 3. Therefore, the infiltration rate in No. 1 decreased, and the hydraulic retention time was extended, so $\mathrm{N}$ immobilization in soil was improved in No. 1.

Fig. 3b) shows that the TP contents at different depths before the inflow were slightly lower than that after, except for $10 \mathrm{~cm}$ in No. 3. It shows that some $\mathrm{P}$ was intercepted

Table 4. Statistics of TOC, TN, and TP in bioretention tanks.

\begin{tabular}{|c|c|c|c|c|c|c|c|c|c|c|c|}
\hline & Depth & Item & $\begin{array}{l}\text { Average } \\
\left(\mathrm{g} \mathrm{kg}^{-1}\right)\end{array}$ & $\begin{array}{c}\text { Standard } \\
\text { deviation } \\
\left(\mathrm{g} \mathrm{kg}^{-1}\right)\end{array}$ & $\begin{array}{c}\text { Variable } \\
\text { coefficient } \\
(\%)\end{array}$ & $\begin{array}{l}\text { Maxi- } \\
\text { mum } \\
\left(\mathrm{g} \mathrm{kg}^{-1}\right)\end{array}$ & $\begin{array}{l}\text { Mini- } \\
\text { mum } \\
\left(\mathrm{g} \mathrm{kg}^{-1}\right)\end{array}$ & $\begin{array}{c}\text { Skew- } \\
\text { ness } \\
S_{k} \\
\end{array}$ & $\begin{array}{c}\text { Kurtosis } \\
K_{u}\end{array}$ & $\begin{array}{l}\text { Confidence } \\
\text { lower limit }\end{array}$ & $\begin{array}{l}\text { Confidence } \\
\text { upper limit }\end{array}$ \\
\hline \multirow{3}{*}{ No. 1} & $10 \mathrm{~cm}$ & \multirow{3}{*}{ TN } & 0.392 & 0.032 & 8.186 & 0.472 & 0.331 & 0.629 & 1.591 & 0.3699 & 0.4534 \\
\hline & $30 \mathrm{~cm}$ & & 0.409 & 0.045 & 10.969 & 0.497 & 0.356 & 0.847 & -0.434 & 0.3989 & 0.5056 \\
\hline & $50 \mathrm{~cm}$ & & 0.363 & 0.031 & 8.465 & 0.453 & 0.324 & 1.529 & 3.976 & 0.3435 & 0.4229 \\
\hline \multirow{3}{*}{ No. 1} & $10 \mathrm{~cm}$ & \multirow{3}{*}{ TP } & 1.187 & 0.125 & 10.530 & 1.347 & 0.876 & -0.686 & 0.999 & 1.0642 & 1.3943 \\
\hline & $20 \mathrm{~cm}$ & & 1.154 & 0.083 & 7.171 & 1.222 & 0.951 & -0.467 & 1.593 & 1.0404 & 1.2669 \\
\hline & $30 \mathrm{~cm}$ & & 1.079 & 0.094 & 8.756 & 1.202 & 0.830 & -1.032 & 1.721 & 0.9488 & 1.2074 \\
\hline \multirow{3}{*}{ No. 1} & $10 \mathrm{~cm}$ & \multirow{3}{*}{ TOC } & 7.192 & 0.707 & 9.829 & 8.616 & 5.941 & 0.218 & -0.649 & 5.6474 & 7.1404 \\
\hline & $30 \mathrm{~cm}$ & & 6.305 & 0.603 & 9.559 & 7.742 & 5.247 & 0.581 & 1.002 & 5.0379 & 6.4060 \\
\hline & $50 \mathrm{~cm}$ & & 5.887 & 0.697 & 11.835 & 6.893 & 4.236 & -0.257 & -0.243 & 4.3718 & 5.8603 \\
\hline \multirow{3}{*}{ No. 3} & $10 \mathrm{~cm}$ & \multirow{3}{*}{$\mathrm{TN}$} & 0.389 & 0.026 & 6.734 & 0.445 & 0.360 & 1.243 & 0.891 & 0.3659 & 0.4347 \\
\hline & $30 \mathrm{~cm}$ & & 0.389 & 0.022 & 5.759 & 0.434 & 0.352 & 0.151 & -0.265 & 0.3668 & 0.4257 \\
\hline & $50 \mathrm{~cm}$ & & 0.388 & 0.027 & 6.940 & 0.474 & 0.363 & 2.313 & 6.553 & 0.3568 & 0.4301 \\
\hline \multirow{3}{*}{ No. 3} & $10 \mathrm{~cm}$ & \multirow{3}{*}{$\mathrm{TP}$} & 1.153 & 0.075 & 6.500 & 1.301 & 1.022 & 0.142 & -0.671 & 1.0191 & 1.2137 \\
\hline & $20 \mathrm{~cm}$ & & 1.103 & 0.103 & 9.331 & 1.216 & 0.910 & -0.132 & -0.947 & 0.9487 & 1.2152 \\
\hline & $30 \mathrm{~cm}$ & & 1.137 & 0.094 & 8.305 & 1.337 & 0.922 & -0.065 & 1.263 & 0.9668 & 1.2189 \\
\hline \multirow{3}{*}{ No. 3} & $10 \mathrm{~cm}$ & \multirow{3}{*}{ TOC } & 7.106 & 1.250 & 17.588 & 8.965 & 4.804 & -0.664 & -0.302 & 4.4480 & 7.2345 \\
\hline & $20 \mathrm{~cm}$ & & 6.555 & 1.053 & 16.072 & 8.454 & 4.883 & -0.316 & -0.175 & 4.4281 & 6.9336 \\
\hline & $30 \mathrm{~cm}$ & & 6.069 & 0.859 & 14.148 & 7.577 & 4.586 & 0.321 & -0.529 & 4.2029 & 6.0399 \\
\hline
\end{tabular}


in soil media when stormwater runoff flowed through the bioretention tanks. Because TP consists of dissolved $\mathrm{P}$ (DP) and particulate P (PP), and PP absorbed on the tiny suspended solids in the tanks were intercepted in soil media after precipitation and filtration. The removal of DP mainly relied on soil media filtration and absorption, which were accomplished through ion exchange and absorption, respectively. With inflow continuing, the compactness of the media below $30 \mathrm{~cm}$ depth in No. 1 was improved to be greater than that in No. 3. Therefore, the infiltration rate in No. 1 decreased, and the hydraulic retention time was extended. The improvement of $\mathrm{P}$ interception and absorption in No. 1 was greater than that in No. 3 within the upper $30 \mathrm{~cm}$ depth. Hence, Fig. 3b) shows that the TP variation before the inflow was greater than after the inflow at the same depth $(10$ and $30 \mathrm{~cm})$ in No. 1 compared to No. 3.

Variations in soil TN and TP at different depths are shown in Table 4. The lowest average TN and TP contents were found at $50 \mathrm{~cm}$ in No. 1, indicating that TN and TP contents were mainly concentrated at 10 30 $\mathrm{cm}$ in soil media in the bioretention tanks. The average TN content in No. 3 decreased with increasing depth, and the TP content at $20 \mathrm{~cm}$ was less than those in the other layers $(10$ and $30 \mathrm{~cm})$. Plant roots are mainly concentrated at $20 \mathrm{~cm}$ in the soil, and absorption of available $\mathrm{P}$ at $20 \mathrm{~cm}$ was slightly greater than that at the other layers. The maximum and minimum TN and TP contents in the 2 tanks were similar at different depths, and their variability was minimal. In addition, the variation coefficient of TN content at $30 \mathrm{~cm}$ and TP content at 10 $\mathrm{cm}$ in No. 1 were higher than $10 \%$ (10.97\% and $10.53 \%$ respectively), which were less than $10 \%$ at other depth in the 2 tanks, with a least of $5.76 \%$. By using the variation coefficient of soil properties, Wilding [30] classified small variations as less than $15 \%$, medium variation between $11 \sim 35 \%$, and high variation as more than $35 \%$. The variation coefficients of TN and TP contents were less than $15 \%$ at different depths, which belongs to small variation. This illustrated that $\mathrm{TN}$ and $\mathrm{TP}$ contents were uniform spatial distribution in the bioretention tanks. The average confidence interval of the average TP content was greater than that of TN content at a confidence level of 95\% (Table 4). Hence, soil TN exhibited a more uniform spatial distribution.

\section{TOC Variation in Bioretention Tanks}

\section{Temporal Variation of TOC}

Figs 4(a-b) show that the TOC content was low in the early stage, but increased on 6 June and decreased on 11 July 11 in No. 1, and changed with time in No. 3 during the whole experimental process. This trend may be attributed to the rebound of environment temperature and gradual increase of soil temperature at the early stage. The plant remants and other organic matter that were most completely degreded last year began to accelerate decay. This led to a gradual increase in the TOC content in soil. When summer came, the environmental temperature was high in Xi'an, and the plants grew vigorously, leading to the consumption of large amounts of $\mathrm{C}$ in soil. Furthermore, the plant roots absorbed a large quantity of nutrients, and required vast $\mathrm{C}$ sources and eventually reduced the

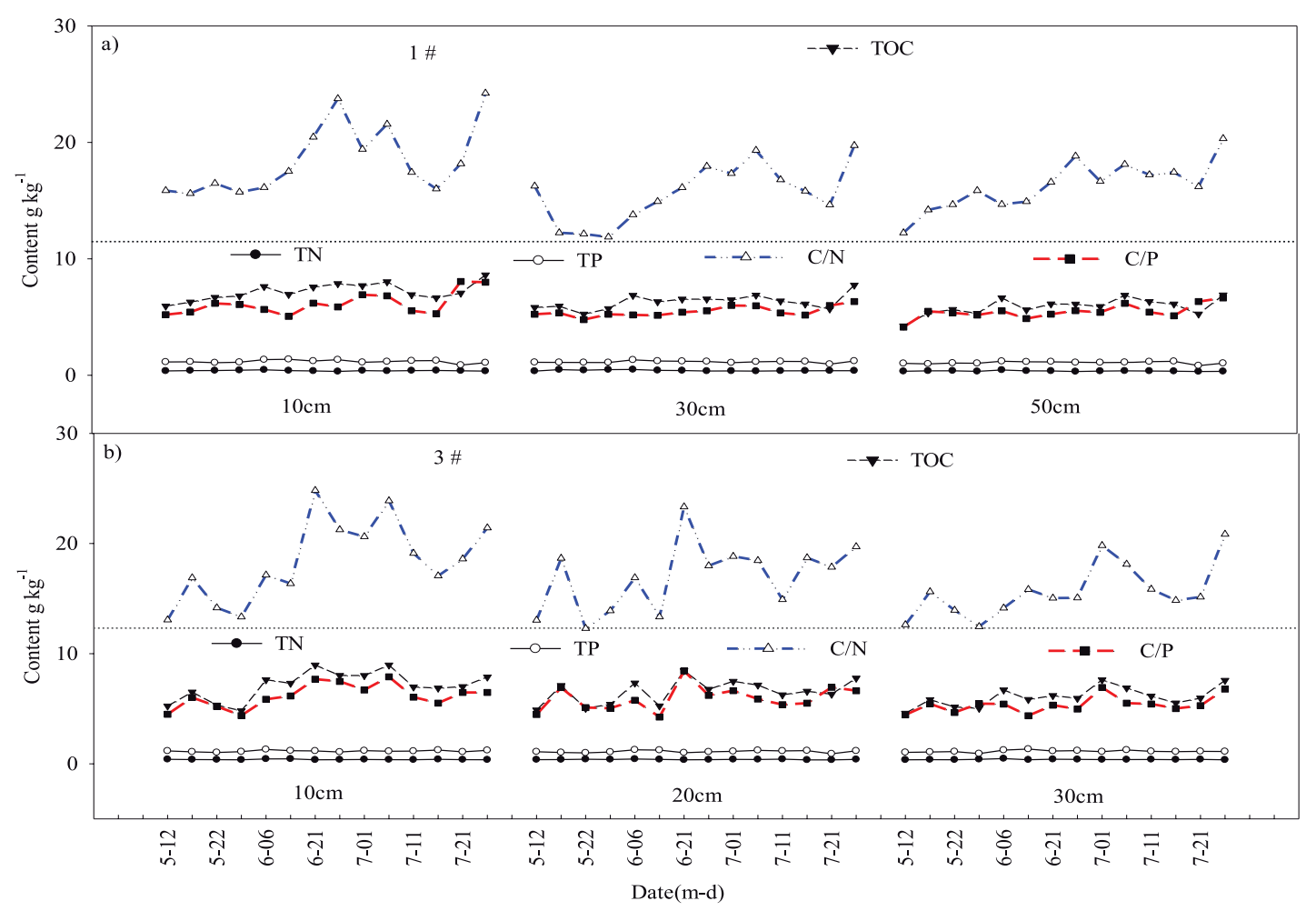

Fig. 4. Relationships of TN, TP, TOC, C/N, and C/P at different depths. 
TOC content in soil. Microorganism activity could be inhibited to a certain extent because the nutrient supply in the soil did not meet the needs of plants and microbes at the same time. Therefore, the soil carbon source can present a dynamic balance between consumption and decomposition.

\section{Spatial Variation of TOC}

It shows that the TOC content in the 2 bioretention tanks varied from $4.24 \mathrm{~g} \mathrm{~kg}^{-1}$ to $8.97 \mathrm{~g} \mathrm{~kg}^{-1}$, and it was lower at $50 \mathrm{~cm}$ than that at 10 and $30 \mathrm{~cm}$ in No. 1 (Figs $4 a-b)$. This result can be attributed to the low amount of organic matter as a result of the introduction of a new filter medium in the 2 bioretention tanks in October 2013. Moreover, other studies showed that soil organic matter was mainly concentrated in the plant root zone, specifically about $20 \mathrm{~cm}$ below the surface [14, 31].

Table 4 shows that the average TOC content in the bioretention tanks decreased with increasing depth, and the lowest value was recorded at $50 \mathrm{~cm}$ in No. 1. This situation showed that TOC was mainly concentrated at $10 \sim 30 \mathrm{~cm}$ in the soil. The differences of the maximum and minimum TOC content were small at the other depths and maintained at about 1.5 times in 2 bioretention tanks, except for at $10 \mathrm{~cm}$ in No. 3 (2.03 times). The variation coefficients of TOC at different depths in No. 1 were less than $15 \%$, indicating a small variation. However, they were more than $15 \%$ at different depths in No. 3, categorized as medium variation; it even reached $18.79 \%$ at $10 \mathrm{~cm}$ in No. 3, which is classified as a large variation. Hence, the spatial distribution of TOC content in No. 1 was more uniform than that in No. 3. It was confirmed based on the large confidence interval of TOC in No. 3 than that in No. 1 at 95\% confidence level.

\section{Relationships of TOC, TN, TP, C/N, and C/P with Different Depths in Bioretention Tanks}

$\mathrm{N}$ and $\mathrm{P}$ can be removed once stormwater runoff entered the bioretention tank through various physical, chemical, and biological comprehensive processes, such as mechanical filtration, sedimentation, absorption, ion exchange, and plant and microbial uptakes. Carbon (C) is related to $\mathrm{N}$ and $\mathrm{P}$ in soil. Thus, in the present study it determined the contents of TOC, TN, and TP and their relationships in bioretention tanks.

\section{$C / N$ and $C / P$ at Different Depths in Bioretention Tanks}

Soil $\mathrm{C} / \mathrm{N}$ can be used to evaluate the mineralization level of $\mathrm{N}$ in the soil. This parameter indicates the conversion of $\mathrm{N}$ to available $\mathrm{N}$ for plant consumption or soil fixation ability on $\mathrm{N}$ [32]. Soil $\mathrm{C} / \mathrm{P}$ can be used to measure the microbial mineralization of soil organic matter to release $\mathrm{P}$ or determine the potential of plants to absorb or immobilize $\mathrm{P}$ in the environment [33]. Some studies showed that $\mathrm{C} / \mathrm{N}$ higher or lower than
30 is the threshold of nitrate $\left(\mathrm{NO}_{3}-\mathrm{N}\right)$ leaching risk [20]. By analyzing the relationship of forest soil $\mathrm{N}_{2} \mathrm{O}$ emission and $\mathrm{C} / \mathrm{N}$, Ernfos et al. [34] reported that $88 \% \mathrm{~N}_{2} \mathrm{O}$ of the world's greenhouse gases were released from forest soil if the $\mathrm{C} / \mathrm{N}$ in the soil was less than 13 . Moreover, other researchers [35] have demonstrated that $\mathrm{C} / \mathrm{N}$ higher than 20 would limit the mineralization rate of soil organic matter on $\mathrm{N}$ and $\mathrm{P}$. In this study, the $\mathrm{C} / \mathrm{N}$ was high but the $\mathrm{C} / \mathrm{P}$ was relatively low (Figs $4 \mathrm{a}-\mathrm{b}$ ). At a depth of $10 \mathrm{~cm}$, the $\mathrm{C} / \mathrm{N}$ in No. 1 varied from 15.61 to 24.23 in No. 1, with an average of 18.46 , and it was maintained from 13.06 to 24.81 in No. 3, with an average of 18.41. At the depth of $30 \mathrm{~cm}$, the $\mathrm{C} / \mathrm{N}$ in No. 1 ranged from 12.14 to 19.73 , and the average was 15.64. However, this parameter was maintained from 12.46 to 20.84 , with an average of 15.67 in No. 3. A minor $\mathrm{C} / \mathrm{N}$ difference was observed at the same depth in Nos. 1 and 3. However, the $\mathrm{C} / \mathrm{N}$ at $10 \mathrm{~cm}$ was greater than that at $30 \mathrm{~cm}$ in 2 tanks. It showed that solute transport or leaching of soil $\mathrm{N}$ occurred with the incease of soil depth. Furthermore, the average $\mathrm{C} / \mathrm{N}$ at $10 \mathrm{~cm}$ in No. 1 was slightly higher than that in No. 3, while it was adverse at $30 \mathrm{~cm}$. The average $\mathrm{C} / \mathrm{N}$ value at $10 \mathrm{~cm}$ and $30 \mathrm{~cm}$ depth in No. 1 is 17.05, which is greater than 17.04 in No. 3. This showed that the immobilization of No. 1 on $\mathrm{N}$ is higher than that of No. 3 on N within the upper $30 \mathrm{~cm}$ depth. This was due to different infiltration rates of underlying fillers below $30 \mathrm{~cm}$ depth of the 2 bioretention tanks, which led to the different interception or immobilization of $\mathrm{N}$ within the $30 \mathrm{~cm}$ in soil layer.

Soil with high $\mathrm{C} / \mathrm{P}$ exhibits high potential for $\mathrm{P}$ fixation [19]. In this study, at the same depth of $10 \mathrm{~cm}$ (Figs 4a-b), the $\mathrm{C} / \mathrm{P}$ varied from 5.06 to 8.06 with an average of 6.17 in No. 1, and it ranged from 4.38 to 7.90 with an average of 6.17 in No. 3. However, when the depth was increased to $30 \mathrm{~cm}$, the $\mathrm{C} / \mathrm{P}$ varied from 4.78 to 6.34 with an average of 5.48 in No. 1, and it ranged from 4.37 to 6.93 with an average of 5.34 in No. 3. There were no differences of the average $\mathrm{C} / \mathrm{P}$ in the 2 bioretention tanks at $10 \mathrm{~cm}$, while it was slightly higher in No. 1 than that in No. 3 at $30 \mathrm{~cm}$. It showed that the immobilization of No. 1 on P is higher than that of No. 3 within the upper $30 \mathrm{~cm}$ depth, which may be related to the different underlying fillers below $30 \mathrm{~cm}$ depth of the two bioretention tanks.

The differences in TP interception in No. 1 and No. 3 were small at $10 \mathrm{~cm}$ depth, although the capacity for TN fixation in No. 1 was higher than that in No. 3. When the depth was increased to $30 \mathrm{~cm}$, the differences in TN absorption in the two bioretention tanks was small, but TP fixation in No. 1 was better than that in No. 3 . This situation is consistent with the results of $\mathrm{TN}$ and TP variations shown in Figs 3(a-b). The characteristic differences of the two bioretention tanks were due to different hydraulic retention times in planting soil layer resulting from the infiltration rate of different underlying fillers, which led to the differences in interception or immobilization of TN and TP in the soil layer. Although the immobiolization of No. 1 on $\mathrm{N}$ and $\mathrm{P}$ was greater than those of No. 3 on $\mathrm{N}$ and $\mathrm{P}$ within the upper $30 \mathrm{~cm}$ 
depth, through systematic research on water quality of the influent and effluent for simulation stormwater runoff, our research team found that the comprehensive purification effects of TN and TP in No. 3 were better than in No. 1
[36], which could be attributed to the strong absorption effect function of the blast furnace slag mixing sand under the planting soil layer in No. 3 .
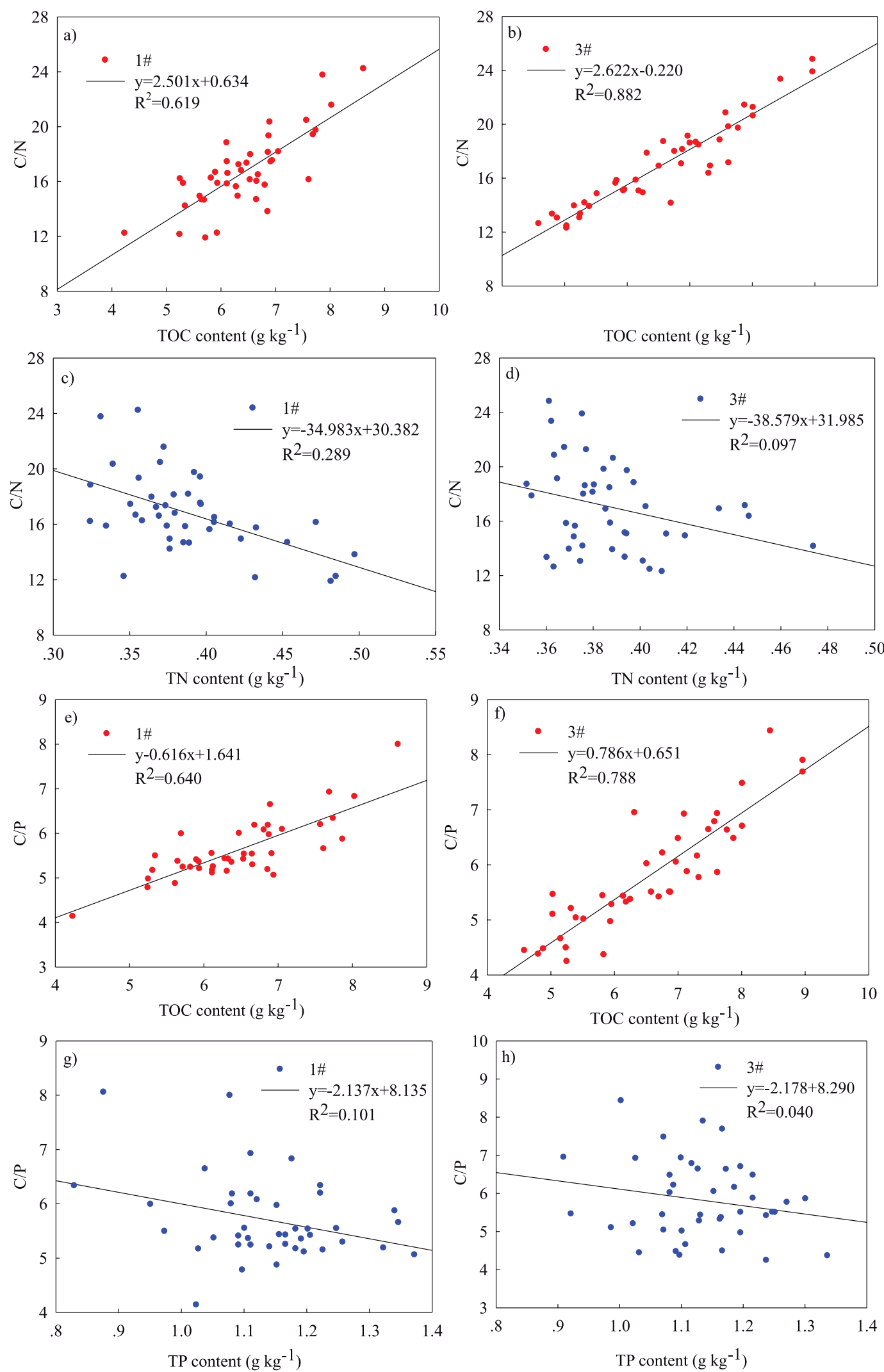

Fig. 5. Relationships of soil $\mathrm{C} / \mathrm{N}$ and $\mathrm{C} / \mathrm{P}$ with soil TOC, $\mathrm{N}$, and $\mathrm{P}$ content in bioretention tanks. 
Relationships of Soil C/N and C/P with Soil TOC, $\mathrm{TN}$, and TP Content in Bioretention Tanks

The relationships of soil $\mathrm{C} / \mathrm{N}$ and $\mathrm{C} / \mathrm{P}$ with soil TOC, $\mathrm{TN}$, and TP content in bioretention tanks are shown in Figs 5(a-h). Soil $\mathrm{C} / \mathrm{N}$ was positively correlated with TOC in No. 1 and No. 3, and $R^{2}$ values were 0.62 and 0.88, respectively (Figs 5a-b). However, they were negatively correlated with $\mathrm{TN}$ content, although the correlation was not obvious as the $\mathrm{R}^{2}$ values were 0.29 and 0.10 in No. 1 and No. 3, respectively (Figs 5c-d). Soil C/P was also correlated with TOC in 2 tanks, and $\mathrm{R}^{2}$ values reached 0.64 and 0.79 in No. 1 and No. 3 (Figs 5e-f). However, they were negatively correlated with TP content, and the correlation was not obvious. The $\mathrm{R}^{2}$ values were 0.10 and 0.04 in Nos. 1 and 3, respectively (Figs $5 \mathrm{~g}-\mathrm{h}$ ). This showed that soil $\mathrm{C} / \mathrm{N}$ and $\mathrm{C} / \mathrm{P}$ were mainly controlled by TOC in soil.

\section{Conclusions}

This study mainly used outdoor bioretention tanks with rain simulation to measure the contents of soil TOC, $\mathrm{TN}$, and TP, and to determine their purification effect on simulation stormwater runoff. We arrived at the following conclusions:

1) Soil TN and TP in the bioretention tanks were mainly concentrated within $10 \mathrm{~cm}$ to $30 \mathrm{~cm}$ depth in soil. The $\mathrm{TN}$ and TP content was high at the early stage and declined over the short span time of the study. TN content before the inflow was slightly higher than that after. TP content before the inflow was lower than that after. The TN content in Nos. 1 and 3 varied from 0.32 $\mathrm{g} \mathrm{kg}^{-1}$ to $0.50 \mathrm{~g} \mathrm{~kg}^{-1}$ within the investigated zone, and the change trends with time were basically identical. And the TP content in Nos. 1 and 3 varied from 0.83 $\mathrm{g} \mathrm{kg}^{-1}$ to $1.35 \mathrm{~g} \mathrm{~kg}^{-1}$ within the investigated zone, and the change trends were also basically identical. The variability of TN and TP was all less than $15 \%$ and classified as small variation. This demonstrated the uniform spatial distribution of TN and TP.

2) The potential of TN and TP fixation in No. 1 was higher than that in No. 3 within the upper $30 \mathrm{~cm}$ depth. The characteristic differences in the planting soil layer of the two bioretention tanks were due to the different infiltration rates of underlying fillers, which led to the differences in interception or immobilization of TN and TP in the planting soil layer.

3) The TOC content was small, ranging from $4.24 \mathrm{~g} \mathrm{~kg}^{-1}$ to $8.97 \mathrm{~g} \mathrm{~kg}^{-1}$, and the average decreased with decreasing depth and was mainly concentrated within $10 \mathrm{~cm}$ to $30 \mathrm{~cm}$ depth in soil. TOC variability No. 1 was all less than $15 \%$ and classified as small variation. However, such variability was more than $15 \%$ in No. 3 and was thus categorized as a medium variation.

4) $\mathrm{C} / \mathrm{N}$ was high but the $\mathrm{C} / \mathrm{P}$ was relatively low. $\mathrm{C} / \mathrm{N}$ and $\mathrm{C} / \mathrm{P}$ were positively correlated with TOC, while they were not obvious with $\mathrm{TN}$ and $\mathrm{TP}$ content, and the correlation was not obvious. Soil $\mathrm{C} / \mathrm{N}$ and $\mathrm{C} / \mathrm{P}$ were mainly controlled by TOC.

\section{Acknowledgements}

This research was supported by the Natural Science Foundation of Shaanxi Province (No. 2015JZ013) and the National Natural Science Foundation of China (No. 51279158).

\section{References}

1. DADI T., RUBIO E., MARTÍNEZ-GARCÍA E., LÓPEZSERRANO F.R., ANDRÉS-ABELLÁN M., GARCÍAMOROTE F.A., De las Heras J. Post-wildfire effects on carbon and water vapour dynamics in a Spanish black pine forest. Environment Science and Pollution Research, 22 (7), 4851, 2015.

2. HANSEN W.D., ROMME W.H., BA A., TURNER M.G. Shifting ecological filters mediate postfire expansion of seedling aspen (Populus tremuloides) in Yellowstone, Forest Ecology Management. 362, 218, 2016.

3. UPADHYAY A.K., BANKOTI N.S., RAI U.N. Studies on sustainability of simulated constructed wetland system for treatment of urban waste: Design and operation, Journal of Environmental Management. 169, 285, 2016.

4. CHEN X.L., PELTIER E., STURM B.S.M., YOUNG BRYAN C. Nitrogen removal and nitrifying and denitrifying bacteria quantification in a stormwater bioretention system. Water Research, 47 (4), 1691, 2013.

5. LI J.K., DAVIS A.P. A unified look at phosphorus treatment using bioretention. Water Research, 90, 141. 2016.

6. RIYA S., ZHOU S., KOBARA Y., SAGEHASHI M., TERADA A., HOSOMI M. Influence of nitrogen loading and plant nitrogen assimilation on nitrogen leaching and $\mathrm{N}_{2} \mathrm{O}$ emission in forage rice paddy fields fertilized with liquid cattle waste. Environmental Science and Pollution Research, 22 (8), 5762, 2015.

7. TROWSDALE S.A., SIMCOCK R. Urban stormwater treatment using bioretation. Journal of Hydrology, 397 (34), 167, 2011.

8. CLAR M., BARFELD B.J, O'CONNOR T.P. Stormwater best management practices design guide volume 2 vegetative biofilters U.S. Environmental Protection Agency Washington DC EPA/600/R-04/121a. 2004.

9. BAEK S.S., CHOI D.H., JUNG J.W., LEE H.J., LEE H., YOON K.S., CHO K.H. Optimizing low impact development (LID) for stormwater runoff treatment in urban area, Korea: Experimental and modeling approach. Water Research, 86, 122, 2015.

10. FUDALA-KSIAZEK S., LUCZKIEWICZ A., FITOBOR K., OLANCZUK-NEYMAN K. Nitrogen removal via the nitrite pathway during wastewater co-treatment with ammonia-rich landfill leachates in a sequencing batch reactor. Environment Science \& Pollution Research, 21 (12), 7307, 2014.

11. AN X.F., LI M.Z., ZHENG L.H., SUN H. Eliminating the interference of soil moisture and particle size on predicting soil total nitrogen content using a NIRS-based portable detector. Computers \& Electronics in Agriculture, 112 (C), 47, 2015. 
12. JI G.D., WANG R.J., ZHI W., LIU X.X., KONG Y.P., TAN Y.F. Distribution patterns of denitrification functional genes and microbial floras in multimedia constructed wetlands. Ecological Engineering, 44 (3), 179, 2012.

13. ZHI W., YUAN L., JI G.D., HE C.G. Enhanced long-Term nitrogen removal and quantitative molecular mechanism in tidal flow constructed wetlands. Environment ScienceTechnology, 49 (7), 4575, 2015.

14. LOZANO-GARCÍA B., PARRAS-ALCÁNTARA L., BREVIK E.C. Impact of topographic aspect and vegetation (native and reforested areas) on soil organic carbon and nitrogen budgets in Mediterranean natural areas. Science of the Total Environment, 544 (8), 963, 2016.

15. QIN H.P., LI Z.X., FU G.T. The effects of low impact development on urban flooding under different rainwater characteristics. Journal of Environmental Management, 129 (18), 577, 2013.

16. VILLAMIL M.B., NAFZIGER E.D. Corn residue, tillage, and nitrogen rate effects on soil carbon and nutrient stocks in Illinois. Geoderma, s 253-254, 61, 2015.

17. PAROLARI A.J., PORPORATO A. Forest soil carbon and nitrogen cycles under biomass harvest: Stability, transient response, and feedback. Ecological Modelling, 329, 64, 2016.

18. YANG J.S., LIU J.S., HU X.J., LI X.X., WANG Y., LI H.Y. Changes of soil organic carbon, nitrogen and phosphorus concentrations under different land uses in marshes of Sanjiang Plain. Acta Ecologica Sinica, 33 (6), 332, 2013.

19. HUME A., CHEN H.Y.H., TAYLOR A.R., KAYAHARA G.J., MAN R.Z. Soil C:N:P dynamics during secondary succession following fire in the boreal forest of central Canada. Forest Ecology Management, 369, 1, 2016.

20. GUNDERSON P., CALLESEN I., VRIES W.D. Nitrate leaching in forest ecosystems is controlled by forest floor $\mathrm{C} / \mathrm{N}$ ratio. Environment Pollution, 102, 403, 1998.

21. LU J.S., CHENG Y., ZHENG Q., DU R., WANG S.P., WANG J.P. Derivation of rainstorm intensity formula in Xi'an city. China water \& wastewater. 26 (17), 82, 2010 [In Chinese].

22. State environmental protection administration of China. Soil-Determination of Total Phosphorus by alkali fusion Mo-Sb Anti spectrophotometric method (HJ632-2011). China environmental science press Beijing, 2011 [In Chinese].

23. State environmental protection administration of China. Soil quality-Determination of total nitrogen, Modified Kjeldahl method (HJ717-2014). China environmental science press Beijing, 2014 [In Chinese].
24. BAO S.D. Soil and agricultural chemistry analysis. Chinese Agricultural Press Beijing, 2008 [In Chinese].

25. LIU S.B., RAZAVI B., SU X., MAHARJAN M., ZAREBANADKOUKI M., BLAGODATSKAYA E., KUZYAKOV Y. Spatio-temporal patterns of enzyme activities after manure application reflect mechanisms of niche differentiation between plants and microorganisms. Soil Biology \& Biochemistry, 112, 100, 2017.

26. GARRIDO F., SERRANO S., BARRIOS L., URUÑUELA J., HELMHART M. Preferential flow and metal distribution in a contaminated alluvial soil from São Domingos mine (Portugal). Geoderma, 213, 103, 2014.

27. LI L.Q., DAVIS A.P. Urban stormwater runoff nitrogen composition and fate in bioretention systems. Environmental Science \& Technology Environ, 48 (6), 3403, 2014.

28. MORALES V.L., GAO B., STEENHUIS T.S. Grain surface-roughness effects on colloidal retention in the vadose zone. Vadose Zone Journal, 8 (1), 11, 2009.

29. GUO C., LI J.K., LI H.E., LIANG Z. Soil Nitrogen Speciation and the Relationship with Microbial Biomass Carbon in Bioretention Tanks. Water air \& Soil Pollution, 227, 474, 2016.

30. WILDING L.P. Spatial variability: Its documentation, accommodation and implication to soil survey. Spatial Variations Wageningen, 1985.

31. JESUS J., CASTRO F., NIEMELÄ A., BORGES M.T., DANKO A.S. Evaluation of the Impact of Different Soil Salinization Processes on Organic and Mineral Soils. Water air \& Soil Pollution, 226 (4), 1, 2015.

32. LI L.Z., HE C.G., JI G.D., ZHI W., SHENG L.X. Nitrogen removal pathways in a tidal flow constructed wetland under flooded time constraints. Ecological Engineering, 81, 266, 2015.

33. WANG P.F., HU B., WANG C., LEIY.Phosphorus absorption and sedimentation by suspended sediments from Zhushan Bay, Taihu Lake. Environmental Science and Pollution Research. 22 (9), 6559, 2015.

34. ERNFORS M., ARNOLD K. VON., STENDAHL J., OLSSON M., KLEMEDTSSON L. Nitrous oxide emissions from drained organic forest soils-an up-scaling based on C:N ratios. Biogeochemistry, 84 (2), 219, 2007.

35. SPRINGOB G., KIRCHMANN H. Bulk soil $\mathrm{C}$ to $\mathrm{N}$ ratio as a simple measure of net $\mathrm{N}$ mineralization from stabilized soil organic matter in sandy arable soils. Soil Biology \& Biochemistry, 35 (4), 629, 2003.

36. ZHANG S.C. Middle experiment of biological filter purifying urban road runoff. Xi'an University of Technology Xi'an, 2015 [In Chinese]. 
